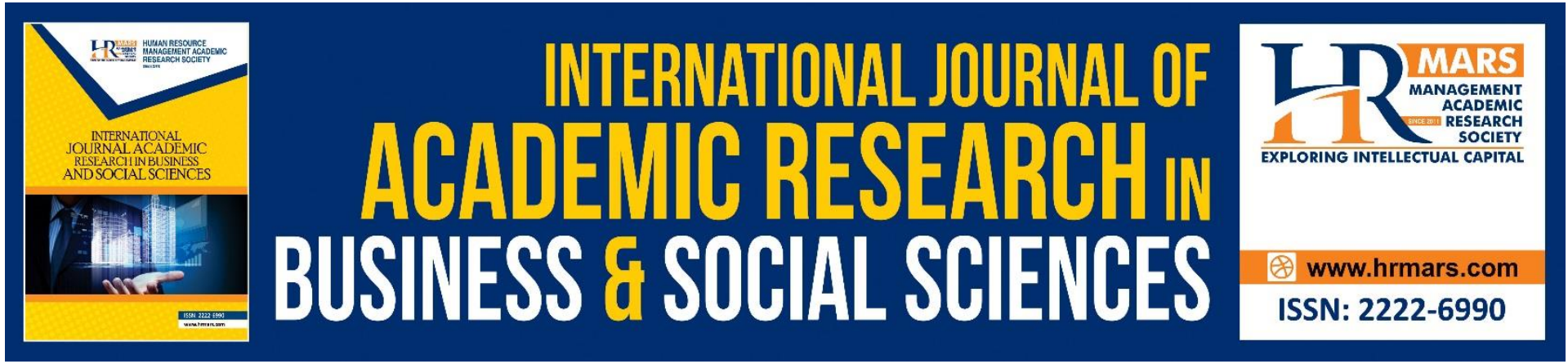

\title{
Tasawuf Approach to Dealing with Crime Among People with Phsycal Disability
}

\section{Khazri Osman, Mohd Fuaad Abdullah Rahim}

To Link this Article: http://dx.doi.org/10.6007/IJARBSS/v11-i6/10391

DOI:10.6007/IJARBSS/v11-i6/10391

Received: 15 April 2021, Revised: 18 May 2021, Accepted: 30 May 2021

Published Online: 25 June 2021

In-Text Citation: (Osman \& Rahim, 2021)

To Cite this Article: Osman, K., \& Rahim, M. F. A. (2021). Tasawuf Approach to Dealing with Crime Among People with Phsycal Disability. International Journal of Academic Research in Business and Social Sciences, 11(6), 1756-1765.

\section{Copyright: @ 2021 The Author(s)}

Published by Human Resource Management Academic Research Society (www.hrmars.com)

This article is published under the Creative Commons Attribution (CC BY 4.0) license. Anyone may reproduce, distribute, translate and create derivative works of this article (for both commercial and non-commercial purposes), subject to full attribution to the original publication and authors. The full terms of this license may be seen at: http://creativecommons.org/licences/by/4.0/legalcode

Vol. 11, No. 6, 2021, Pg. 1756 - 1765

Full Terms \& Conditions of access and use can be found at http://hrmars.com/index.php/pages/detail/publication-ethics 


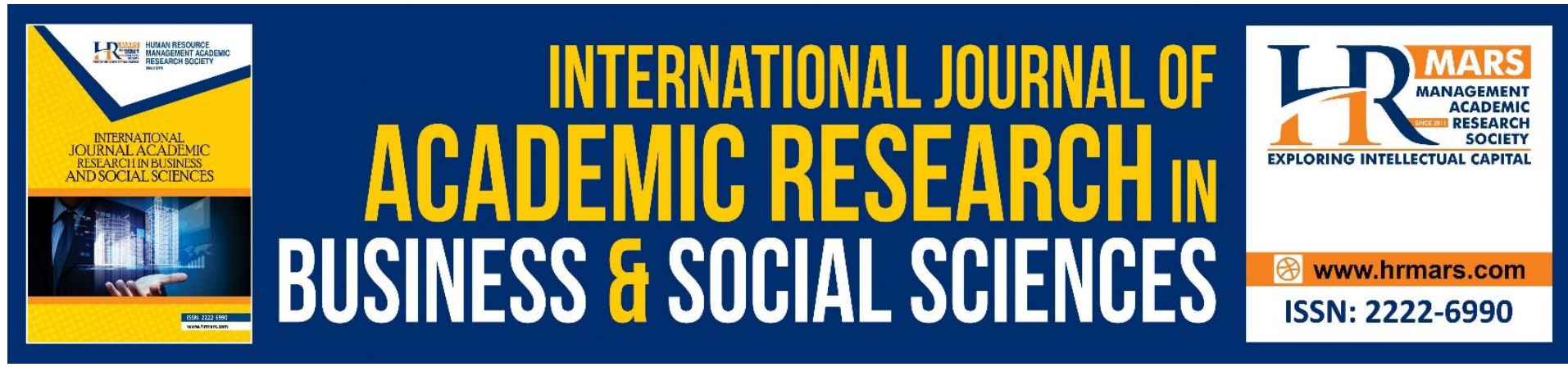

\title{
Tasawuf Approach to Dealing with Crime Among People with Phsycal Disability
}

\author{
Khazri Osman \\ Research Centre for Dakwah and Leadership Faculty of Islamic Studies National University of \\ Malaysia
}

Mohd Fuaad Abdullah Rahim

Research Centre for Dakwah and Leadership Faculty of Islamic Studies National University of Malaysia

\begin{abstract}
The Person with Disabilities (PWDs) community is one of the groups that always gets the attention of society. They are being privileged with their due rights to ensure a safe and comfortable life. At the same time, however, this community is not exempted in committing wrongs and crimes, even though their number is less than that of their abled counterparts. This research adopts a qualitative analysis on documents which include media documents and Sufi works to analyze the crime activities committed by the PWDs. To aid this community, a Sufi approach is proposed, which emphasizes more on the spiritual aspects while also not marginalizing the physical aspects. This research finds that there are five tașawwuf methods that can be applied as recommended by the Sufis. Among them are instilling understanding in order to develop moral probity, striving to change one's self, surrounding one's self with good companions, and getting spiritual treatments. This research succeeds in explaining the comprehensiveness of the tașawwuf approach that is suitable not only for the abled community, but also the PWDs community.
\end{abstract}

Keywords: Tasawwuf, Approach, Da'wah, Disabled People, Crime.

\section{Introduction}

PWDs are individuals with long-term disabilities whether physically, mentally, intellectually, or sensorily who, when are faced with various obstacles, cannot probably involve themselves fully and effectively in the society. This community is part of the society. They have rights and rights to opportunities that are equal to the other members of the society to live their lives with the same standards as others. A rights-based approach and protection are apt to be adopted to ensure the interests and well-being of the PWDs community. In Malaysia, the PWDs community is divided into two groups: special children and old citizens. Special children can be defined as children who are different from their normal peers in some respects such as mental capacity, communication skills, social behaviors, physical attributes, and others. The PWDs community can also be divided into another categorization based on the types of disability: permanent and temporary. Permanent disabilities include organ defects, hearing 
defects, vision defects, mental retardance, and effects of old age. On the other hand, temporary disabilities include injuries, illness, and pregnancy (Dzulkifli, 2018). In Malaysia, PWDs are managed by the Ministry of Women, Family and Community Development (KPWKM). According to the Department of Community Wellbeing (JKM), PWDs are encouraged to register under this agency in order to be informed of the population count, density, and categories of PWDs in this country so as to allow the planning of programs that are related to preventing, educating, habilitating, rehabilitating, training as well as for the purpose of providing facilities that are suitable to the needs of the PWDs.

\section{The Crime Scenario: The Rights and Crimes of Phsycal With Disabilities in Malaysia}

Malaysia sits at the $4^{\text {th }}$ place in the crime index rate for the Asian region, reported by Numbeo, a global database site. However, the said index that was published in the mid-year of 2020 shows a drop to $58.55 \%$ as compared to $60.66 \%$ at the same point of time last year, at once proving an increase in the scale of safety of this country from $39.34 \%$ (mid-year 2019) to $41.45 \%$ (mid-year 2020). Afghanistan recorded the highest crime rate with a rate of $76.97 \%$, followed by Syria (67.42 \%) and Bangladesh (63.82 \%). Meanwhile, according to a worldwide comparison, Malaysia sits at the $26^{\text {th }}$ place from 133 countries. The index of crime ratio for a population of 100,000 Malaysians in 2018 has improved to 273.8 compared to 309.7 in 2017. Seven States recorded a crime index above the national level in 2018 which included the Federal Territory of Kuala Lumpur (642.6), Selangor (330.8), Negeri Sembilan (327.1), Melaka (303.6), Kedah (287.6), Pulau Pinang (284.6), and Johor (275.7). On the other hand, Terengganu recorded the lowest crime index for year 2018 (148.4) (Mahiddin, 2019). In reality, the crime index in Malaysia has recorded a decline for over 11 years since 2009. According to the Director of Bukit Aman's Department of Crime Investigation, Datuk Huzir Mohamed, a number of 212,678 cases were recorded in 2009, and the number has declined since to 84,485 cases in 2020 . This decline has been regarded as drastic with a record of 11,000 lesser cases since 2009. For burglary index, there were 38,570 cases recorded in 2009, compared to only 16,498 cases recorded in 2020. Even the number of bank robberies recorded a significant decrease with only less than five cases recorded every year since 2009. And no such cases were recorded in 2015 and 2016. In 2020, there were only two cases but were still under control. Victims are the most important element in a crime incident. Diagram 1.1 shows the index of crime ratio for a population of 100,000 Malaysians in 2016-2018: 
Diagram 1.: index of crime ratio for a population of 100,000 Malaysians in 2016-2018:

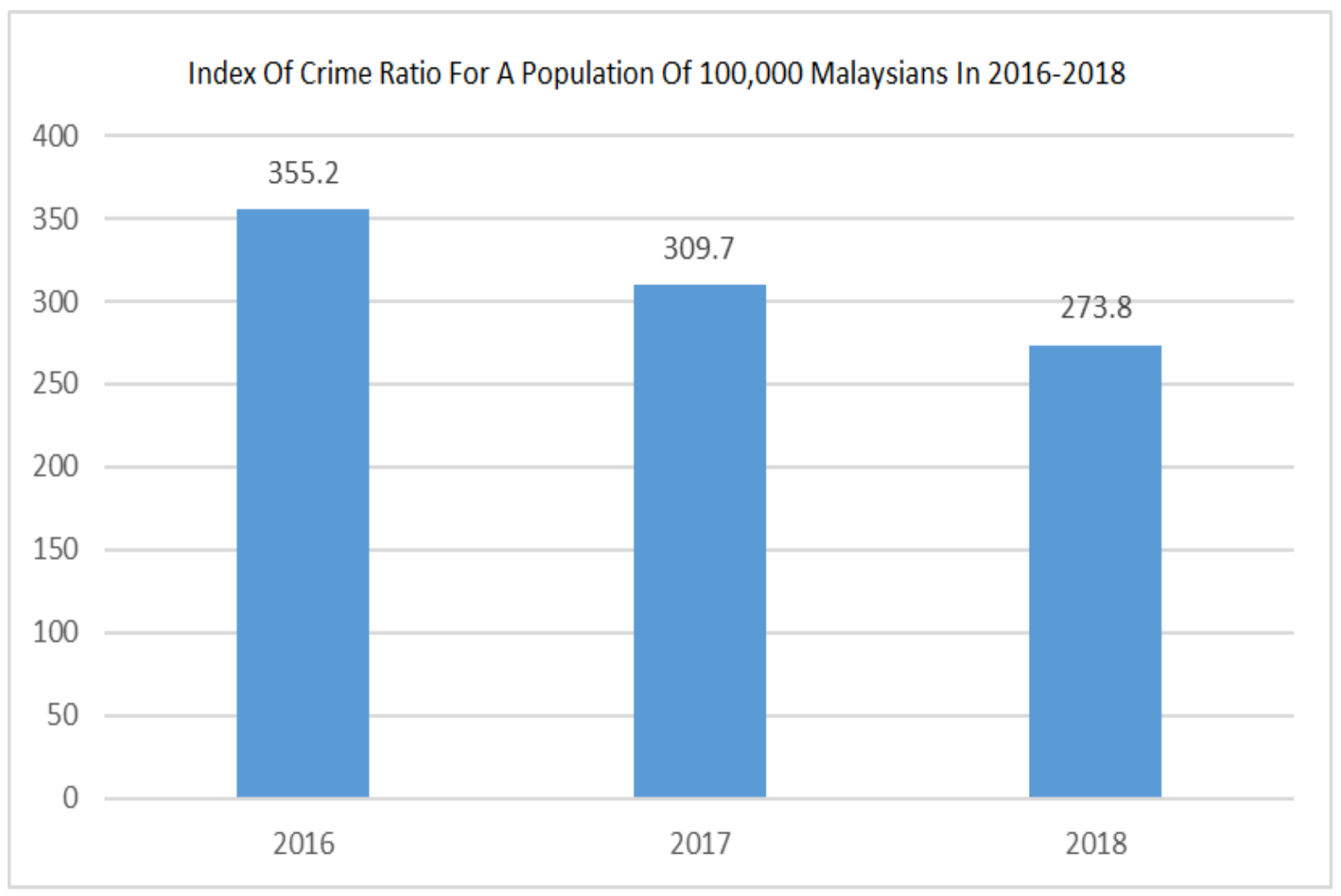

Social problems are a phenomenon of modernization and a form of culture shock that raves all groups. The crisis of confusion that overwhelms a person, if not curbed and overcome, can aggravate the already existing social problems. And this phenomenon is a threat to the national human resources that can be harmful to the nation in the long-term. Therefore, these problems that are faced by the teenagers demand a solution so that they cease to create a huge threat to the development of the nation. And since the PWDs are also part of the society, therefore, they, too, are not exempted from committing crimes. Schedule 1.2 shows a media report on the involvement of the PWDs in crime cases in Malaysia in 2016-2021: 
Schedule 1.2: Media Report on the Involvement of the PWDs in Crime Cases in Malaysia in 2016-2021.

\begin{tabular}{|l|l|l|l|l|l|l|l|}
\hline Jenayah/Media & $\begin{array}{l}\text { Harian } \\
\text { Metro }\end{array}$ & $\begin{array}{l}\text { Utusan } \\
\text { Borneo }\end{array}$ & $\begin{array}{l}\text { Berita } \\
\text { Harian }\end{array}$ & $\begin{array}{l}\text { Astro } \\
\text { Awani }\end{array}$ & $\begin{array}{l}\text { Utusan } \\
\text { Malaysia }\end{array}$ & Kosmo & $\begin{array}{l}\text { Sinar } \\
\text { Harian }\end{array}$ \\
\hline Khalwat & 1 & & & & & & \\
\hline Drugs & 4 & 1 & 1 & & 1 & 1 & \\
\hline $\begin{array}{l}\text { Attempted } \\
\text { Suicide }\end{array}$ & 1 & & & & & & \\
\hline Breach of Trust & & & 1 & & & & \\
\hline $\begin{array}{l}\text { Attempted } \\
\text { Killing }\end{array}$ & & & & 1 & & & \\
\hline Gambling & 2 & & & & & & \\
\hline Violating Honor & 1 & & 1 & & & & \\
\hline Stealing & & & & & & & \\
\hline
\end{tabular}

Schedule 1.2 shows that the crime in which PWDs are most involved is substance abuse. Youths and teenagers are the age groups that have the highest statistics in this predicament. Realizing their potential as an asset for the future of the country, the government through responsible authorities emphasizes seriously on the efforts to eradicate and treat the problem of substance abuse among these age groups. This awareness is also based on the awareness that youths and teenagers comprise the largest portion of the Malaysian population. Within this age range, they are said to be the most important of human resources due to them being described as energetic, competent, and exhibit the highest productivity. In fact, the youths are the generation that will lead the country in the future. However, substance abuse can influence their health in a harmful way and, consequently, affect their productivity level negatively. And health is an important aspect in ensuring the physical, psychological, and social qualities that enable an individual to manage himself and others properly in any given situations. There are no crimes where there are no victims. The theory of opportunity crime states that even if a person possesses a criminal motive, but does not have the chance to acquire a victim, then a crime is not considered to have taken place. PWDs are also crime victims. The occurrence of a crime does not only involve a pushing factor, but the opportunity to acquire a victim is also a factor that contributes to the occurrence of a crime (Tang \& Darit, 2015).

The PWDs community should be given suitable rights along with the changing tides of time, including those that are related to the basic human rights. In the modern interpretation of human rights, there are three important documents pertaining to this topic which include The Universal Declaration of Human Rights 1948, the International Covenant on Civil and Political Rights 1966, and the International Covenant on Economic, Social and Cultural Rights 1966. In both of the international conventions above, the human rights are not limited only to the provisions of the law of civil and political rights such as the freedom of speech, freedom of religion, freedom of assembly and organization, freedom from torture and fairness as well as rights that are under the social, economic, and cultural rights such as the rights to education, 
job opportunities and recreation, minimum healthcare services, and safe residence and environment. Knowledge of a certain issue, especially the issue of PWDs, is very crucial. Every man and woman, regardless of their abilities and disabilities, gender, socio-economic and socio-cultural status, ethnicity, and religion, has an equal right as others to attain a good life. Among the rights of the PWDs are access to public facilities, equal job opportunities, education opportunities and social interaction opportunities. According to WHO, $15 \%$ of the population of a given country consisted of the PWDs community. This clearly shows that the PWDs are not just a minority of a country. Hence, real efforts should be done to ensure their involvement in the various aspects of the country's development. Compared to other countries, Malaysia's policies with regards to the PWDs are still welfare-based. This should be overcome since even PWDs, just like other normal human beings, demonstrate exceptional qualities and potential that could prove to be beneficial to themselves and others. Therefore, efforts should be doubled so as to shift the paradigm of PWDs rights to be based on development and equal rights in all aspects of life (Rosli et al., 2015). After the launch of the PWDs policy and action plan in 2007, the government took the initiative to draft the Person With Disabilities Act 2008 as a part of the government's commitment to the international covenant of human rights. This Act is the first to provide protection and rights for the PWDs community in Malaysia.

This Act, consisting of 46 Sections and 5 Parts, generally outlines a guideline pertaining to the National Council for PWDs, PWDs' registration, as well as the improvement of their life and wellbeing. Two of the main institutions that have the authority and responsibility to implement this Act are the National Council for PWDs as described under Section 3 to 18, and the Department for the Development of Persons with Disabilities (DDPWDs) as described under Section 10. The government is very committed in empowering the PWDs through various policies since 1988 until now. Nevertheless, the empowerment efforts are not easy to be implemented in a short period of time. For example, until 2014, the PWDs participation in the working sector did not even reach 1\%. The One Percent Policy (Dasar Satu Peratus) that was introduced in 1988 was enhanced by the Number 16 Service Circular (Pekeliling Perkhidmatan Bilangan 16) 2010 that came in force on $15^{\text {th }}$ December 2010. According to a statistic provided by the Public Service Department (JPA), until 2016, there were a number of 3446 workers that were consisted of PWDs in the public sector, which included five individuals from the highest management, 900 individuals from the professional and management groups, and 2541 individuals from the executives. These numbers include individuals with different types of disabilities: 1261 (physical disabilities), 23 (mental disabilities), 770 (various disabilities), 276 (hearing disabilities), 677 (visual disabilities), 36 (speech disabilities) and 41 (learning disabilities). In the legal aspect, the PWDs Act 2008 generally provides a good opportunity to promote the rights of the PWDs community. Still, this Act is not exempted from criticism due to the absence of any penalty provisions whenever a lawsuit and negligence occur to the authorities. Section 41 and 42 of PWDs Act 2008 clearly provide a protection for the government and the National Council for PWDs if there happens any forms of negligence and carelessness (Tah, 2018). From one side, the PWDs community is given an equal right to the abled communities.

\section{The Tasawuf Approach}

Al-Junayd al-Baghdadi defines tașawwuf as the process of purifying one's self from the animalistic impulses, emphasizing man's perfection, supressing one's desire, holding firm to 
the knowledge of truth and the teachings of the Prophet s.a.w. Al-Qushayri views tașawwuf as spreading the teachings of the Quran and the Sunnah, fighting against the lowly human desires (haw $\left.\bar{a}^{\prime}\right)$, avoiding innovations (bid'ah), suppressing the inappropriate sexual drive (shahwat), and treating heedlessness (ghaflah) in performing ibādah. Essentially, there are five elements in tașawwuf: knowledge, practice, internalization, and wajd and fana '. These definitions give a picture of tașawwuf as enabling a person to arrive at the reality of truth by detaching one's self from the worldly pleasures. A person who practices tașawwuf is indifferent or, in fact, averse towards the worldly pleasures due to the fact that it can disturb one's 'ibādah and one's relationship with God (Kamarzaman, 2018). According to al-Qushayri, a Sufi scholar, knowledge and practice in tașawwuf emphasize on the purification of the soul, internalizing good character and ridding bad moral qualities. The emphasis on nurturing knowledge and practice in tașawwuf can instil in a Muslim individual the fear of God (taqwā) and His Oneness. By doing so, a person's heart is cleansed and, therefore, enables him to arrive at the truth and the knowledge of God (mairifatuLlāh). A Muslim cannot neglect the concepts of knowledge and practice because the realization of them both is crucial for the attainment of God's Mercy (rahmah) and Satisfaction (riḍa). The process of spiritual training of a Muslim depends on his sincerity (ikhlāș) and determination (juhūd) in increasing his knowledge and deeds in tașawwuf as a source to empower one's identity (Abdullah, 2017). Tașawwuf is also synonymous to the science of akhlāq and tazkiyah al-nafs. Hence, Muslim scholars who studied tașawwuf also emphasized on akhlāq.

Naturally, humans are created to have a tendency towards everything good, beautiful, honourable, and dignified while at the same time are averse towards anything bad, ugly, and profane (Osman et al., 2020). Nevertheless, as humans, the lowly desires always come in the way of performing 'ibādah. And because even the PWD community is involved with crimes, therefore they too should be helped with various methods including the tașawwuf approach, beginning with the process of strengthening their faith (imān). The methods, as outlined by al-Ghazali, are instilling the pillars of imān through four steps. The process begins with memorizing the pillars of imān and followed by understanding them, that is, by constructing the understanding through a disclosing of its meanings gradually. Then, the understandings are held to as beliefs (itiqād) and are verified (tașdīq) with certainty. The processes recommended by al-Ghazali involve two main levels in the human being. The first are the memorization and mental comprehension, while the second are the faith and certainty in the self. The PWD community should be given the understanding, as described by Ibn Miskawayh, a Muslim ethician, that the purpose of every religion is to instil good character. This purpose is not attainable unless every individual believes that religion is something essential for the soul. According to Ibn Miskawayh also, every individual should be rewarded even in this world based on their level and status. One is not eligible to demand for more than what is due for him and cannot lessen what is given to him. One of the factors that causes the social problems is the lacking in religious education among parents as well as children. A lacking in knowledge, application, and practice of religion does very little to help children in developing their behaviour positively. Individuals who are privileged with positive guidance from their families as well as possessing an acute religious awareness are able to face a challenging situation and indirectly preventing them from involving themselves in doing wrongs (Ibrahim, et al., 2012). According to Mohd Huzairi, the reality is that religious understandings within the society are now really weak. There are instances where individuals do not even know the basic knowledge of 'aqīdah and 'ibādah including performing the obligatory prayers, not observing 
fasting without remorse, and shamelessly committing sins and impieties, but are hesitant in doing good things, disrespectful towards their parents, distant from the mosques as well as falling into irreligiosity easily. This phenomenon is caused by the imbalance between spiritual and ethical development and the scientific and technological enterprises, as well as the failure in making religion as the source of guidance in their modern life (Husain, 2017).

The PWDs should strive to change themselves. According to Ibn Miskawayh, akhlāq is the main factor that determines the well-being of a society as well as for the transformation of the self and the society. Moral probity can also be attained by the striving of every individual aside from some specific trainings and educations. Ibn Miskawayh also outlines a guideline for internalizing the concept of cooperation ( $\operatorname{ta}(\bar{a} w u n)$, that is: if one contributes a lot by helping others out, one is worthy of help himself. On the other hand if one's help to others is small, then one is only worthy of a small help. He also advises to prevent one's self from committing injustices. Every individual is advised to always be cautious in their actions by training the mind to have gentleness. According to Abu Nasir Muhammad bin al-Farakh alFarabi, an imperfect mind who does not know happiness causes unhappiness and restlessness in the soul. This is different from the views held by the philosophers who thought that the mind does not influence the soul because, to them, the human perfection lies in the mind knowing happiness and misery (Tajudin, 2017).

Appropriately, the PWDs should be allowed to lead a communal life. Ibn Miskawayh opines that a comprehensive moral life is not practicable in a solitary context. This is because only in a communal life can the values of cooperation, gentleness, and compassion can be practiced. He opposes the hermit lifestyle because this lifestyle does not allow man to have a moral life. One must not isolate himself from the society because a societal life can benefit him a lot in the sense that only through the society can he have access to the knowledge of good and bad. People who distance themselves from the society, according to Ibn Miskawayh, are considered to have committed injustice due to them depriving the society from the potential benefits that they can contribute. People who do not help others while expecting help from others are unjust and can be considered as public enemies. If they think that their lives depend only so much on others, they must realize that others are depending on them a lot (Muhamad et al., 2004). The PWDs should not only depend on others for their sustenance. They must have faith that God is the Sustainer. At the same time, they must not abandon the efforts of acquisition (kasb) because it comes along with delegation (tawakkal). If one believes in the efficacy of his own efforts in providing himself with sustenance without ascribing it to God's mercy, he might fall into the pitfalls of blasphemous association (shirk) because he is tacitly ascribing God with impotence. However, denying the efficacy of efforts altogether can result in self-oppression (jabariyyah) (Osman, 2014).

The PWDs must be surrounded with or find good companions for themselves. According to Ibn Miskawayh, the human population is consisted more of naturally morally defective people than the morally upright ones. Between these groups, there are also people who are morally intermediate. This group is morally subject to the kinds of companionship that they have. If they befriend good people, they will tend towards good things. Meanwhile, if they befriend bad people, then they will tend towards bad things. Man begins to form companionship with individuals outside of family relationship. In the beginning, man begins to associate himself with his neighbours, and when he goes to any schooling institutions, his circle becomes wider 
and wider. In short, with the increase in maturity, people tend to grow interest in others around them. According to al-Ghazali, companionship is likened to a family. A strong friendship strengthens the relationship between individuals, and it is obligatory to fulfil the rights of a friend. Therefore, friendship is defined by al-Ghazali as people being in proximity with each other, mingling with each other, having mutual love and respect, based on good values by doing good towards each other and resulting in mahabbah (Bakar et al., 2013).

PWDs also should not sideline the importance of spiritual treatment. A healthy soul should be nurtured with the deepening of true knowledge. This can be done by surrounding one's self with the presence of pious and knowledgeable people, acquiring beneficial knowledge from them, aside from distancing one's self cautiously from mingling with crooked people, madmen, grave sinners, people who take pride from their sins and careful from fulfilling their mischievous invitations. For PWDs diseased with envy, among the admonitions by al-Mandili, a Sufi scholar, is to continuously praise and express happiness for the blessings enjoyed by others as well as observing humility in one's self. With this, the envied victims will become his friends and, subsequently, his envy evaporates. Furthermore, al-Mandili also advises that the internal envy should not be externalized physically, and animosity should not be bred whenever envy kicks in. In fact, it is advisable to not express pleasure at the loss of others (Muhsin, 2013).

\section{Conclusion}

Islam emphasizes justice towards all of mankind regardless of their status and conditions rich, poor, old, healthy, perfect and imperfect and more. Through good interaction and good $\bar{a} d \bar{a} b$ with others, harmony in the society can be achieved. Meanwhile, the society should have respect towards the PWDs community and vest to them their due rights since their presence invites an abundance of goodness (barakah) and happiness (sa'ādah). As human beings, even the PWD communities are not exempted from making mistakes. Therefore, there should be a handful of methods adopted to help them including the methods of tașawwuf. Sufis and scholars of ethics such as al-Ghazali, Ibn Miskawayh, and al-Mandili focus on the importance of instilling proper understandings, striving to change one's self, associating with good companies, and getting spiritual treatments as means to produce good character and moral standing. Although the approaches analysed in this article are more suitable for physical and non-mental disabilities, it does not necessarily mean that other criteria are marginalized.

\section{Corresponding Author}

Mohamad Zulkifli Abdul Ghani, Research Centre for Dakwah and Leadership Faculty of Islamic Studies National University Of Malaysia, Malaysia, zulghani@ukm.edu.my

\section{References}

Abdullah, M. S., \& Syed Omar, S. H. (2017). Konsep Ilmu dan Amal Dalam Tasawuf. Proceeding International Conference of Empowering Islamic Civilization 2017, (pp. 444-448).

Bakar, M. S., Long, A. S., \& Bakar, I. A. (2013). Perspektif Aristotle dan Al-Ghazali Terhadap Konsep Persahabatan. Jurnal Hadhari, 5(1), 21-36.

Dzulkifli, I., \& Suhid, A. (2018). Pendidikan Islam Pemangkin Modal Insan OKU Muslim. Journal of Quran Sunnah Education and Special Needs, 2(2), 37-45. 
Husain, M. H. (2017). Penghayatan Fardu Ain Remaja Pekak Di Malaysia. Thesis, Universiti Malaya, Akademi Pengajian Islam, Kuala Lumpur.

Ibrahim, F., Sarnon, N., Alavi, K., Mohamad, M. S., Akhir, N. M., \& Nen, S. (2012). Memperkasakan Pengetahuan Agama Dalam Kalangan Remaja Bermasalah Tingkah Laku: Ke Arah Pembentukan Akhlak Remaja Sejahtera. Journal of Social Sciences and Humanitiesence, 7(1), 84-93.

Kamarzaman, M. H. (2018). Pengenalan Terhadap Institusi Tasawuf di Malaysia: Tarekat Naqshabandiyyah Khalidiyyah. 3rd International Seminar on Islamic Thought (pp. 203219). Selangor: National University of Malaysia.

Mahidin, M. U. (2019). Statistik Jenayah 2019. Jabatan Perangkaan Malaysia. https://www.dosm.gov.my/v1/index.php?r=column/pdfPrev\&id=OWZSTkRPbGxwRE pFbjRjZ2w1OUVGUT09

Muhamad, S. N., Ripin, M. N., \& Muhamad, M. D. (2004). Pemupuk Akhlak Muslim Menurut Pandangan Ibnu Miskawayh. Seminar Antarabangsa Nilai Dalam Komuniti Pasca Modenisme, (pp. 1-11).

Muhsin, S. B., \& Sa'ari, C. Z. (2013). Beberapa Aspek Psikoterapi Islam Dalam Kitab Jawi, 'Penawar Bagi Hati' Oleh Sheikh Abdul Qadir Al-Mandili. Jurnal Akidah \& Pemikiran Islam, 14(1), 109-142.

Osman, K., \& Tibek, S. R. (2014). Nilai Spiritual Dalam Puisi Imam Shafi'i. Jurnal Al-Hikmah, 6, 51-65.

Osman, K., Abdul Ghani, M. Z., Mohamad, A. D., \& Mokhtar, A. I. (2020). Keindahan Gaya Bahasa Simile Dalam Hadis Ashrat Al-Sa'ah. Jurnal Al-Turath, 5(1), 1-10.

Rosli, H. F., Wan Mahmud, W. A., \& Mahbob, M. H. (2015). Realiti dan Kesamarataan Hak Orang Kelainan Upaya (OKU) Di Malaysia Dari Perspektif Media. International Conference on Media and Communication, (pp. 1-15).

Tah, I. H., \& Mokhtar, K. A. (2018). Basic Human Rights for Persons with Disabilities in Malaysia: An Analysis. Jurnal Kanun Undang-Undang, 1(30), 109-136.

Tajudin, A. R. (2017). Kedudukan Dan Peranan Akal Di Sisi Ahli Tasawuf. Jurnal Sultan Alauddin Sulaiman Shah, 76-81.

Tang, C. F., \& Darit, S. M. (2015). Penentu Makroekonomi Kadar Jenayah di Malaysia. Jurnal Ekonomi Malaysia, 49(2), 53-60. 